\title{
Poziom zachowań zdrowotnych pacjentów przed incydentem zawału mięśnia sercowego w zależności od wybranych zmiennych socjodemograficznych
}

\author{
Behavior of health level before myocardial infraction depending \\ on sociodemographic variables
}

NATALIA CECOT ${ }^{1}$, DARIA KAŃKOWSKA ${ }^{2}$

1 Państwowa Uczelnia Zawodowa we Włocławku, Instytut Nauk o Zdrowiu

2 Szpital Wielospecjalistyczny im. dr. Ludwika Błażka w Inowrocławiu, Oddział Kardiologii i Oddział Intensywnego Nadzoru Kardiologicznego

http://dx.doi.org/10.21784/IwP.2021.010

\section{Streszczenie}

Wstęp. Zawał mięśnia sercowego zalicza się do grupy ostrych zespołów wieńcowych, którą cechują zaburzenia w krążeniu wieńcowym, co prowadzi do ograniczenia lub całkowitego ustania przepływu krwi w tętnicach wieńcowych. Zdrowie jednostki oraz populacji uzależnione jest od wielu czynników. Współcześnie obowiązujący model zdrowia opublikował Marc Lalonde. Koncepcja ta ukazała jak ważną rolę odgrywa styl życia w kształtowaniu zdrowia jednostki i zbiorowości.

Cel. Celem niniejszej pracy była ocena poziomu zachowań zdrowotnych pacjentów przed incydentem zawału mięśnia sercowego w zależności od wybranych zmiennych socjodemograficznych.

Materiał i metody. Badanie przeprowadzono wśród stu pacjentów z rozpoznanym zawałem mięśnia sercowego, hospitalizowanych w Oddziale Kardiologii i Oddziale Intensywnego Nadzoru Kardiologicznego w Szpitalu Wielospecjalistycznym im. dr. Ludwika Błażka w Inowrocławiu. W pracy wykorzystano metodę szacowania. Narzędziem badawczym wykorzystanym w pracy był kwestionariusz Inwentarza Zachowań Zdrowotnych oraz autorska metryczka. 
Wyniki. W grupie badanych uzyskano całą rozpiętość skali stenowej IZZ. Najwięcej ankietowanych osiągnęło poziom 6 stena, co odpowiada wynikom średnim. Biorąc pod uwagę zmienne socjodemograficzne można zauważyć, że kobiety częściej uzyskiwały wyniki średnie, a mężczyźni wyniki niskie. Ankietowani z wykształceniem wyższym przejawiali wysoki poziom zachowań zdrowotnych, natomiast z wykształceniem średnim - średni poziom zachowań. Respondenci legitymujący się wykształceniem podstawowym lub zawodowym wykazywali niski poziom zachowań zdrowotnych. Respondenci pozostający w związku małżeńskim wykazują niski poziom zachowań zdrowotnych, natomiast osoby rozwiedzione średni poziom. Respondenci przebywający na emeryturze osiągnęli średni wynik poziomu zachowań zdrowotnych, natomiast osoby pracujące - niski poziom. Respondenci poniżej 74 roku życia wykazywali niski poziom zachowań zdrowotnych, natomiast osoby w przedziale wiekowym 75-99 lat uzyskiwały wynik średni.

Wnioski. Zachowanie zdrowotne mające wpływ na wystąpienie zawału mięsnia sercowego były zróżnicowane i zależały od zmiennych socjodemograficznych takich jak: płeć, wykształcenie, status zawodowy, stan cywilny, miejsce zamieszkania czy wiek. Najwięcej ankietowanych uzyskało wyniki na poziomie średni. Najmniejsza grupa uzyskała wynik wysoki.

Słowa kluczowe: Zawał mięśnia sercowego, zmienne socjodemograficzne, poziom zachowań zdrowotnych

\section{Abstract}

Admission. Myocardial infraction belongs to group of acute coronary syndromes which are characterized by disturbances in the coronary circulatory systems. That leads to reduction or limitation of blood flow in coronary artery. The health of unit or population depends on a lot of variables. The applicable health model has been published by Marc Lalonde. This concept showed how important is healthy lifestyle role in health shaping.

Aim. Purpose of this study was assessment of patient's health before myocardial infraction depending on sociodemographic variables.

Material and methods. Research has been conducted on group of one hundred patients with recognized myocardial hearth attack hospitalized in Department of Cardiology and the Department of Intensive Cardiac Supervision 
in the name of Ludwik Błażek in Inowroclaw. In this study method that has been used is estimation method. Data from the patients has been taken in questionnaire form. The research tool used in the study was the Health Behavior Inventory questionnaire and the author's record.

Results. In a group of all respondents whole spread of sten scale IZZ has been obtained. The most of respondents has reach 6th level of sten scale, which is related to high average. Taking into account sociodemographic variables we can see that women's more often achieve average results, men achieve low average results. Respondents with higher education level achieves high level of health behaviors, respondents with secondary education reached average level of health behaviors. Respondents with primary or vocational education achieved low level of health behaviors. People that stays in marriage shows a low level of health behaviors. Retired respondents reached average level. People that works - level low. Next was respondents below 74 years old - they showed low level of health behaviors. People between 75 and 99 years old achieved average results level.

Conclusions. Health behaviors that have an impact on occurrence of myocardial infraction was different and depends on sociodemographic variables such as: gender, education, professional status, martial status, place of residence and age. Most of respondents obtained results on average level. The smallest one obtained results on level high.

Keywords: myocardial infractions, sociodemographic variables, level of health behavior

\section{Wstęp}

Zawał mięśnia sercowego zalicza się do grupy ostrych zespołów wieńcowych, którą cechują zaburzenia w krążeniu wieńcowym, co prowadzi do ograniczenia lub całkowitego ustania przepływu krwi w tętnicach wieńcowych. Według danych Ogólnopolskiego Rejestru Ostrych Zespołów Wieńcowych PL-ACS co roku odnotowuje się około 120 tysięcy ostrych zespołów wieńcowych, z czego ok. 73 tysiące stanowią zawały serca [1]. Objawy to m.in. ból w klatce piersiowej, duszność, osłabienie, kołatanie serca, ból w nadbrzuszu. Główne badania, które należy 
zrobić u osoby z podejrzeniem zawału mięśnia sercowego to: badania laboratoryjne - troponina T, troponina I oraz kinaza kreatynowa (CK), EKG (elektrokardiogram), które ujawnia nieprawidłowości w zakresie odcinka ST (uniesienie, obniżenie), zespołu QRS (patologiczny załamek Q dłuższy niż 0,04 sek. i wyższy niż $25 \%$ załamka R), blok odnogi pęczka Hisa, zmiany załamka T (ujemny załamek), zdjęcie rentgenowskie (RTG), echokardiografię (ECHO serca), która ujawnia zaburzenia kurczliwości wywołane przez niedokrwienie spowodowane niedrożnością tętnicy odpowiedzialnej za zawał, a także inne zaburzenia mogące wywoływać ból w klatce piersiowej, niebędące wynikiem niedrożności tętnicy wieńcowej (takie jak: zwężenie zastawki aortalnej, kardiomiopatia przerostowa, zapalenie osierdzia, rozwarstwienie aorty, zatorowość płucna) - koronarografię, czyli inwazyjne badanie pozwalające poznać dokładną budowę i przebieg tętnic wieńcowych oraz dające możliwość wykonania angioplastyki (poszerzenia balonem z wszczepieniem lub bez wszczepienia stentu) zwężonego miejsca w naczyniu [2].

Do zawału mięśnia sercowego przyczynia się kilka czynników. Można je podzielić na dwie grupy: modyfikowalne (zależne) i niemodyfikowalne (niezależne) [3]. Do czynników, które zależą od stylu życia człowieka zalicza się: zaburzenia lipidowe, palenie tytoniu, nadwagę, nadciśnienie tętnicze, cukrzycę, stres oraz nadmierne spożywanie alkoholu. Czynniki niemodyfikowalne to płeć, wiek oraz czynniki genetyczne [3]. Zdrowie jednostki oraz populacji uzależnione jest od wielu czynników.

Współcześnie obowiązujący model zdrowia opublikował Marc Lalonde. Koncepcja ta ukazała jak ważną rolę odgrywa styl życia w kształtowaniu zdrowia jednostki i zbiorowości [4]. Według koncepcji Lalonde'a istnieją cztery determinanty zdrowia: styl życia (53\%), środowisko fizyczne (21\%), czynniki genetyczne (16\%), opieka zdrowotna (10\%). Istnieją niezliczone dowody świadczące o tym, że wielu chorób można było by uniknąć poprzez modyfikację stylu życia, wykluczając niepoprawne zachowania zdrowotne, tj. złe nawyki żywieniowe, zbyt mała aktywność fizyczna, patologiczne otłuszczenie ciała, nadmierne spożywanie alkoholu czy palenie tytoniu. 
W Polsce w 2016 roku modyfikowalne czynniki ryzyka odpowiadały za 35,6\% przyczyn występowania zawału mięśnia sercowego, z czego $17,2 \%$ było związane z dietą, natomiast $14,2 \%$ z palenia tytoniu [5].

\section{Cel}

Celem niniejszej pracy była ocena poziomu zachowań zdrowotnych pacjentów przed incydentem zawału mięśnia sercowego w zależności od wybranych zmiennych socjodemograficznych.

\section{Materiał i metody}

Badanie przeprowadzono wśród stu pacjentów z rozpoznanym zawałem mięśnia sercowego, hospitalizowanych w Oddziale Kardiologii i Oddziale Intensywnego Nadzoru Kardiologicznego w Szpitalu Wielospecjalistycznym im. dr. Ludwika Błażka w Inowrocławiu. W tej pracy wykorzystano metodę szacowania. Narzędziem badawczym wykorzystanym w pracy był kwestionariusz Inwentarza Zachowań Zdrowotnych oraz autorska metryczka.

\section{Wyniki}

Kwestionariuszy IZZ składa się z 24 pytań dotyczących zachowań zdrowotnych wpływających na zdrowie człowieka. Zostały one podzielone na cztery kategorie, tj.: prawidłowe nawyki żywieniowe, zachowania profilaktyczne, praktyki zdrowotne i pozytywne nastawienie psychiczne. Na każde z pytań należało odpowiedzieć w skali od 1 do 5, gdzie poszczególnym cyfrom była przypisana odpowiednia wartość. Cyfra 1 oznaczała odpowiedź prawie nigdy, 2 - rzadko, 3 - od czasu do czasu, 4 - często, 5 - prawie zawsze. Wyniki podlegają przeliczeniu według skali stenowej. Wartości 1-4 charakteryzują wyniki niskie, od 7-10 wyniki wysokie, natomiast wartości 5 i 6 oznaczają wyniki przeciętne.

W tabeli 1. przedstawiono rozkład wyników osób badanych ze względu na wartość stenową. Spośród ankietowanych największą grupę stanowiły osoby $(19 \%, n=19)$, które osiągnęły wartość 6 stenów. Nieco mniej badanych $(18 \%, n=18)$ uzyskało wynik 4 i 5 stena. Najmniejsza 
grupa respondentów, zaledwie 3\% pacjentów (n=3) osiągnęła wartość 9 stena.

Tabela 1. Rozkład wyników osób badanych ze względu na wartość stenową.

\begin{tabular}{|c|r|r|}
\hline Klasa stenowa & n & \% \\
\hline 1 & 6 & 6 \\
\hline 2 & 7 & 7 \\
\hline 3 & 15 & 15 \\
\hline 4 & 18 & 18 \\
\hline 5 & 18 & 18 \\
\hline 6 & 19 & 19 \\
\hline 7 & 7 & 7 \\
\hline 8 & 7 & 7 \\
\hline 9 & 3 & 3 \\
\hline
\end{tabular}

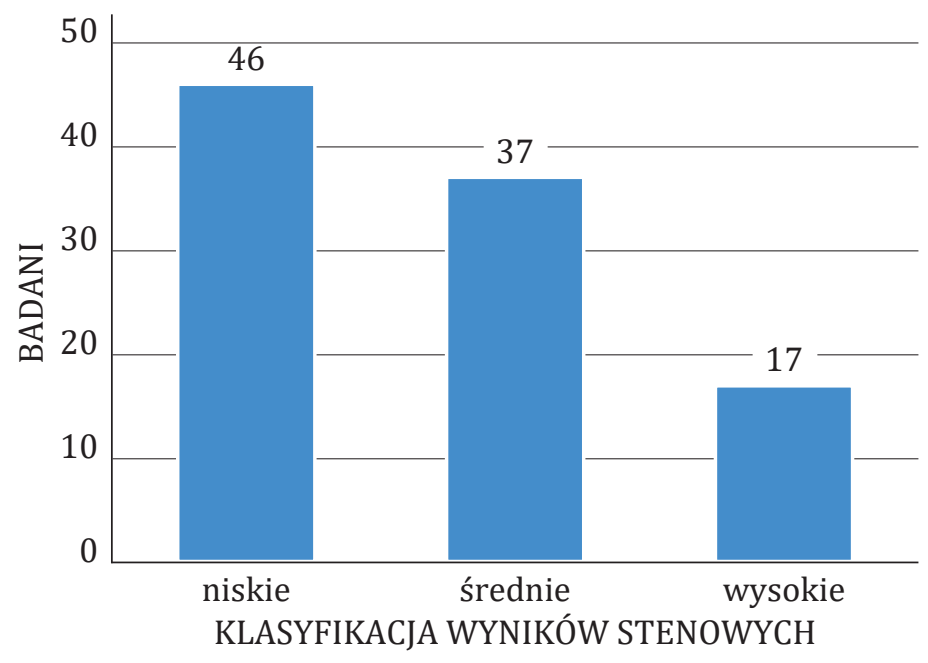

Ryc. 1. Klasyfikacja wyników stenowych uzyskanych przez badanych w ramach weryfikacji poziomu ich zachowań zdrowotnych. 
Na rysunku 1. przedstawiono analizę rozkładu wyników uzyskanych w badanej grupie, która udzielała odpowiedzi na pytania zawarte w Inwentarzu Zachowań Zdrowotnych. Najwięcej osób ankietowanych (46\%, n=46) udzieliło odpowiedzi, których wyniki klasyfikowały się do wyników niskich. Spośród ankietowanych $17 \%$ osób (n=17) uzyskało wyniki wysokie.

Tabela 2. Rozkład klasyfikacji wartości stenowych wśród badanych w zależności od płci.

\begin{tabular}{|c|c|c|c|c|}
\hline & \multicolumn{2}{|c|}{ Kobiety } & \multicolumn{2}{c|}{ Mężczyźni } \\
\hline wartość stenowa & n & {$[\%]$} & n & [\%] \\
\hline wyniki niskie & 10 & 30 & 36 & 54 \\
\hline wyniki średnie & 16 & 48 & 21 & 31 \\
\hline wyniki wysokie & 7 & 22 & 10 & 15 \\
\hline
\end{tabular}

Tabela 2. przedstawia rozkład klasyfikacji wartości stenowych w zależności od płci respondentów. Wśród mężczyzn 54\% z nich ( $\mathrm{n}=36)$ osiągało wyniki niskie, $31 \%(\mathrm{n}=21)$ wyniki średnie, zaś wyniki wysokie 15\% $(\mathrm{n}=10)$. Wśród kobiet proporcje procentowe przedstawiały się odpowiednio: 30\% kobiet $(\mathrm{n}=10)$ prezentowało wyniki niskie, $48 \%$ ( $\mathrm{n}=16)$ wyniki średnie oraz $22 \%(\mathrm{n}=7)$ wyniki wysokie.

Tabela 3. Rozkład klasyfikacji wartości stenowych wśród badanych w zależności od miejsca zamieszkania.

\begin{tabular}{|c|c|c|c|c|}
\hline & \multicolumn{2}{|c|}{ Wieś } & \multicolumn{2}{c|}{ Miasto } \\
\hline wartość stenowa & $\mathbf{n}$ & {$[\%]$} & $\mathbf{n}$ & {$[\%]$} \\
\hline wyniki niskie & 19 & 50 & 27 & 44 \\
\hline wyniki średnie & 10 & 26 & 27 & 44 \\
\hline wyniki wysokie & 9 & 24 & 8 & 13 \\
\hline
\end{tabular}

Tabela 3. prezentuje rozkład wartości stenowych wśród badanych zależny od miejsca zamieszkania. Wśród osób mieszkających na wsi 50\% (n=19) uzyskało wyniki niskie w zakresie poziomu zachowań 
zdrowotnych, 26\% ( $\mathrm{n}=10$ ) wyniki średnie, zaś $24 \%$ (n=9) wyniki wysokie. Wartości procentowe dla wymienionych progów dla osób zamieszkujących w mieście wynosiły odpowiednio 44\% ( $\mathrm{n}=27), 44 \%(\mathrm{n}=27)$ oraz $13 \%(n=8)$.

Tabela 4. Rozkład klasyfikacji wartości stenowych wśród badanych w zależności od poziomu wykształcenia.

\begin{tabular}{|c|c|c|c|c|c|c|c|c|}
\hline & \multicolumn{2}{|c|}{$\begin{array}{c}\text { Podsta- } \\
\text { wowe }\end{array}$} & \multicolumn{2}{c|}{ Zawodowe } & \multicolumn{2}{c|}{ Średnie } & \multicolumn{2}{c|}{ Wysokie } \\
\hline wartość stenowa & $\mathbf{n}$ & {$[\mathbf{\%}]$} & $\mathbf{n}$ & {$[\%]$} & $\mathbf{n}$ & {$[\%]$} & $\mathbf{n}$ & {$[\%]$} \\
\hline wyniki niskie & 8 & 38 & 26 & 53 & 9 & 43 & 3 & 33 \\
\hline wyniki średnie & 7 & 33 & 18 & 37 & 10 & 48 & 2 & 22 \\
\hline wyniki wysokie & 6 & 29 & 5 & 10 & 2 & 10 & 4 & 44 \\
\hline
\end{tabular}

Tabela 4. przedstawia rozkład wartości stenowych w zależności od wykształcenia ankietowanych. $\mathrm{W}$ grupie osób z wykształceniem podstawowym najczęściej badani osiągali niskie $(38 \%, n=8)$ i średnie wyniki (33\%, n=7). W grupie osób z wykształceniem zawodowym odnotowano największy procentowy rozkład wynoszący 53\% (n=26) dla wyników niskich. Wśród osób z wykształceniem średnim najczęściej odnotowywano średni $(48 \%, \mathrm{n}=10)$ i niski $(43 \%, \mathrm{n}=9)$ poziom zachowań zdrowotnych. Zaś w grupie osób o wykształceniu wyższym najczęściej badani przejawiali wysoki poziom zachowań zdrowotnych (44\%; n=4). Do uzyskanych wyników należy odnosić się z dużą ostrożnością ze względu na niską liczebność podgrup, szczególnie osób z wyższym wykształceniem.

Tabela 5. Rozkład klasyfikacji wartości stenowych wśród badanych w zależności od stanu cywilnego.

\begin{tabular}{|c|c|c|c|c|c|c|}
\hline & \multicolumn{2}{|c|}{$\begin{array}{c}\text { Kawaler/ } \\
\text { panna }\end{array}$} & \multicolumn{2}{c|}{$\begin{array}{c}\text { Żonaty/ } \\
\text { mężatka }\end{array}$} & \multicolumn{2}{c|}{$\begin{array}{c}\text { Rozwiedziony/ } \\
\text { rozwiedziona }\end{array}$} \\
\hline wartość stenowa & $\mathbf{n}$ & {$[\%]$} & $\mathbf{n}$ & {$[\%]$} & $\mathbf{n}$ & {$[\%]$} \\
\hline wyniki niskie & 13 & 65 & 25 & 47 & 8 & 30 \\
\hline wyniki średnie & 6 & 30 & 15 & 28 & 16 & 59 \\
\hline wyniki wysokie & 1 & 5 & 13 & 25 & 3 & 11 \\
\hline
\end{tabular}


Tabela 5. przedstawia rozkład wartości stenowych w zależności od stanu cywilnego respondentów. Najczęściej niski poziom zachowań zdrowotnych prezentowali respondenci w grupie osób stanu wolnego $(65 \%, n=13)$ oraz osób pozostających w związku małżeńskim $(47 \%$, $\mathrm{n}=25$ ), natomiast $w$ grupie osób rozwiedzionych przeważały wyniki średnie $(59 \%, \mathrm{n}=16)$.

Tabela 6. Rozkład klasyfikacji wartości stenowych wśród badanych w zależności od statusu zawodowego.

\begin{tabular}{|c|c|c|c|c|c|c|}
\hline & \multicolumn{2}{|c|}{ Pracujący/-ca } & \multicolumn{2}{c|}{ Emeryt/-ka } & \multicolumn{2}{c|}{ Bezrobotny } \\
\hline wartość stenowa & $\mathbf{n}$ & {$[\%]$} & $\mathbf{n}$ & {$[\%]$} & $\mathbf{n}$ & {$[\%]$} \\
\hline wyniki niskie & 14 & 58 & 17 & 29 & 15 & 83 \\
\hline wyniki średnie & 4 & 17 & 30 & 52 & 3 & 17 \\
\hline wyniki wysokie & 6 & 25 & 11 & 19 & 0 & 0 \\
\hline
\end{tabular}

Tabela 6. obrazuje rozkład wartości stenowych w zależności od statusu zawodowego ankietowanych. W grupie pracujących najczęściej badani osiągali niskie wyniki $(58 \%, \mathrm{n}=14)$. W grupie emerytów przeważały wyniki średnie $(52 \%, n=30)$. Natomiast w grupie osób bezrobotnych niemal wszystkie osoby przejawiały wyniki niskie $(83 \%, n=15)$, jedynie 17\% ( $\mathrm{n}=3$ ) wyniki średnie, żaden $\mathrm{z}$ badanych nie osiągnął wyników wysokich.

Tabela 7. Rozkład klasyfikacji wartości stenowych wśród badanych w zależności od wieku.

\begin{tabular}{|c|c|c|c|c|c|c|}
\hline & \multicolumn{2}{|c|}{$\mathbf{2 0 - 5 9}$ r. ż. } & \multicolumn{2}{c|}{$\mathbf{6 0 - 7 4}$ r. ż. } & \multicolumn{2}{|c|}{$\mathbf{7 5 - 9 9}$ r. $\dot{\mathbf{z}}}$. \\
\hline wartość stenowa & $\mathbf{n}$ & {$[\mathbf{[ \% ]}$} & $\mathbf{n}$ & {$[\%]$} & $\mathbf{n}$ & {$[\%]$} \\
\hline wyniki niskie & 21 & 75 & 19 & 46 & 6 & 19 \\
\hline wyniki średnie & 4 & 14 & 15 & 37 & 18 & 58 \\
\hline wyniki wysokie & 3 & 11 & 7 & 17 & 7 & 23 \\
\hline
\end{tabular}

Tabela 7. przedstawia rozkład wartości stenowych w zależności od wieku respondentów. Osoby w przedziale wiekowym do 59 roku życia najczęściej $(75 \%, n=21)$ przejawiały wyniki niskie. Ankietowani w przedziale wiekowym 60-74 r. ż. najczęściej (46\%, n=19) wykazywali 
niski poziom zachowań zdrowotnych. Natomiast osoby z grupy wiekowej 75-99 r. ż. najczęściej (58\%, n=18) osiągali wyniki średnie.

\section{Dyskusja}

W grupie badanych uzyskano całą rozpiętość skali stenowej IZZ. Najwięcej ankietowanych osiągnęło poziom 6 stena, co odpowiada wynikom średnim. Biorąc pod uwagę zmienne socjodemograficzne można zauważyć, że kobiety częściej uzyskiwały wyniki średnie a mężczyźni wyniki niskie. Zbliżony efekt badań uzyskała Grochans i współautorzy [6]. Stwierdzono bowiem, że kobiety przejawiają wyższe nasilenie zachowań zdrowotnych niż mężczyźni. Badania te przeprowadzono na przełomie 2010/2011 roku wśród pacjentów przychodni „Vitaplus” w Trzciance.

Ankietowani z wykształceniem wyższym przejawiali wysoki poziom zachowań zdrowotnych, natomiast $\mathrm{z}$ wykształceniem średnim - średni poziom zachowań. Respondenci legitymujący się wykształceniem podstawowym lub zawodowym wykazywali niski poziom zachowań zdrowotnych. Odzwierciedlenie tych wyników można także znaleźć w badaniach przeprowadzonych przez Grochans i współautorów [6], gdzie wyższy poziom wykształcenia respondentów wpływał na większe nasilenie zachowań zdrowotnych. Respondenci pozostający w związku małżeńskim wykazują niski poziom zachowań zdrowotnych, natomiast osoby rozwiedzione średni poziom. Takie same wyniki zaprezentowali Wysokiński, Dmowska, Fidecki i Dziedzic [7], którzy swoje badania przeprowadzili wśród 100 osób powyżej 65 roku życia.

Respondenci byli pacjentami Szpitala Specjalistycznego im. Kardynała Stefana Wyszyńskiego w Lublinie, Przychodni SPZOZ w Siedlcach lub Osiedla Senioralnego Senior Apartments w Majdanie. Badania realizowano w okresie od kwietnia do maja 2018 roku. Wyniki badań wskazują, że osoby stanu wolnego osiągają wyższy poziom zachowań zdrowotnych, niż osoby pozostające w związku. Respondenci przebywający na emeryturze osiągnęli średni wynik poziomu zachowań zdrowotnych, natomiast osoby pracujące - niski poziom. Badanie przepro- 
wadzone przez Muszalik i wsp. [8], realizowane wśród 110 pacjentów hospitalizowanych w Katedrze i Klinice Geriatrii w Bydgoszczy w 2012 roku wskazują, że respondenci niepracujący osiągali wyższy poziom praktyk zdrowotnych. Respondenci poniżej 74 roku życia wykazywali niski poziom zachowań zdrowotnych, natomiast osoby w przedziale wiekowym 75-99 lat uzyskiwały wynik średni. Takie same tendencje odnotowano w badaniu przeprowadzonym przez Sierakowską i współautorów [9]. Realizowali oni badania wśród 100 pacjentów z rozpoznaną chorobą zwyrodnieniową stawów. Poziom zachowań zwiększał się wraz ze wzrostem wieku respondentów.

\section{Wnioski}

Na podstawie uzyskanych wyników można wyodrębnić następujące wnioski:

1. Zachowania zdrowotne preferowane przez badanych przed wystąpieniem zawału mięśnia sercowego były zróżnicowane i zależały od zmiennych socjodemograficznych, takich jak płeć, wykształcenie, status zawodowy, stan cywilny, miejsce zamieszkania oraz wiek.

2. Największy procent ankietowanych osiągnęło wynik średni. Były to: kobiety, osoby z wykształceniem średnim, rozwiedzione, na emeryturze oraz osoby w przedziale wiekowym 75-99 lat.

3. Wysoki poziom zachowań zdrowotnych osiągnęły osoby z wykształceniem wyższym.

4. Niski poziom osiągnęły osoby: płci męskiej, z wykształceniem podstawowym lub zawodowym, respondenci będący w związku małżeńskim, osoby pracujące i poniżej 74 roku życia.

\section{Zalecenia dla praktyki pielęgniarskiej}

Profilaktyka to szereg działań mających na celu zapobieganie chorobom przed jej rozwinięciem. Przynosi to korzyści dla społeczeństwa w postaci, np. poprawy świadomości zdrowotnych populacji, poprawy stanu zdrowia ludności, zwiększenia wykrywalności chorób we wcze- 
snym stadium rozwoju, zmniejszenia liczby zachorowań i zgonów, obniżenia kosztów leczenia, zmniejszenia absencji chorobowej. Na każdym etapie działań profilaktycznych, również w praktyce pielęgniarskiej, znaczącą role odgrywa edukacja zdrowotna. Jest to proces podczas którego ludzie uczą się dbać o zdrowie własne i innych osób.

Należy zatem podnosić poziom wiedzy populacji na temat zachowań służących zdrowiu poprzez działania informacyjne. Bezpośrednim celem tych prac jest ukształtowanie sprzyjających zdrowiu przekonań, motywacji i umiejętności, a co za tym idzie postaw zdrowotnych jednostki.

\section{Bibliografia/Bibliography}

1. Kaźmierska I. Ostry zespół wieńcowy - zasady postępowania w 2019 r. Puls Medycyny. 2019;10:15-17.

2. Bartoszewicz M., Rać M. Czynniki ryzyka choroby wieńcowej - diagnostyka, leczenie i prewencja. Hygeia Public Health. 2018,3:254-255.

3. Sawicka K., Grządka A., Łuczyk R., Wawryniuk A., Prasal M., Łuczyk M., Daniluk J. Awareness of risk factors for coronary heart disease in patient after myocardial infraction. Journal of Education, Heatlh and Sport. 2016, 12:795-816.

4. Woźniak M., Brukwicka I., Kopański, Z., Kollar R., Kollarova M., Bajger B. Zdrowie jednostki i zbiorowości. Journal of Clinial Healthcare. 2015; 4:1-3.

5. Wojtyniak B., Goryński P. Sytuacja zdrowotna ludności Polski i jej uwarunkowania - synteza. Narodowy Instytut Zdrowia Publicznego - Państwowy Zakład Higieny.Warszawa 2018:243.

6. Grochans E., Gburek D., Polakiewicz P., Jurczak A., Grzywacz A., Szkup- Jabłońska M., Augustyniuk K., Karakiewicz B. The assessment of patients' health behaviours with reference to sociodemographic variables. Family Medicine \& Primary Care Review. 2012;4,2:148-150.

7. Wysokiński M., Dmowska P., Fidecki W., Dziedzic B., Zachowania zdrowotne a akceptacja choroby osób w podeszłym wieku, Geriatria, 2019;13:77-82. 
8. Muszalik M., Zielińska-Więczkowska H., Kędziora-Kornatowska K., Kornatowski T. Ocena wybranych zachowań sprzyjających zdrowiu wśród osób starszych w oparciu o Inwentarz Zachowań Zdrowotnych Juczyńskiego w aspekcie czynników socjodemograficznych. Problemy Higieny i Epidemiologii. 2013;3:509-513.

9. Sierakowska M., Sierakowski S., Wróblewska M., Krajewska-Kułak E. Problemy zdrowotne pacjentów z chorobą zwyrodnieniową stawów i ich wpływ na jakość życia uwarunkowaną stanem zdrowia. Reumatologia. 2010;6:372-379. 